\title{
PEMBERITAAN PEMILIHAN GUBERNUR JAWA BARAT DI MEDIA ONLINE DALAM MEMBENTUK OPINI MAHASISWA
}

\author{
C. Suprapti Dwi Takariani \\ Balai Pengkajian dan Pengembangan Komunikasi dan Informatika Bandung (BPPKI) Bandung \\ Jl.Pajajaran No.88 Bandung- 40173, Jawa Barat, telp.022-6017493, Fax.022-6021740, HP.08122179515 \\ Email:dwi.takariani@gmail.com \\ Naskah diterima tanggal 18 Oktober 2013, disetujui pada tanggal 14 November 2013
}

\section{WEST JAVA GOVERNOR ELECTION NEWS IN ONLINE MEDIA TO ESTABLISH STUDENTS OPINION}

\begin{abstract}
Development of online media, it has become something that is inseparable from political activity homeland. Use of online media in the West Java governor election of 2013 was very suitable for capturing constituents and to establish their opinion. This is possible considering the Province of West Java is one of the Provinces with the largest area and the largest population in Indonesia. The theory used as the basis for this study is theory Agenda Setting. The problem is how far the news Pilgub Jabar 2013 in the online media in to establish students opinion, Faculty of Communication UNIGA Garut West Java Province? The purpose of this study was to analyze the news in 2013 Pilgub Jabar in online media to establish students opinion. The theory used as the basis for this study is Agenda Setting theory. Population is UNIGA Garut Fikom students numbering 81 people, sampling technique is total sample. Data collection techniques based on: library studies and questionnaire. The research shows that in 2013 the news Pilgub Jabar in online media capable formed the students about the gubernor candidate who participated in the gubernor election in 2013, by the vision and mission as well as their work program. It is characterized by confidence, stability, and action of the respondents in the West Java gubernor election in 2013.
\end{abstract}

Keywords: West Java gubernor election news, online media, student opinion.

\begin{abstract}
Abstrak
Perkembangan media online, telah menjadi sesuatu yang tidak terpisahkan dari aktivitas politik tanah air. Pemanfaatan media online pada pemilihan gubenur Jawa Barat (Pilgub Jabar) tahun 2013 sangat cocok dilakukan untuk menjaring konstituen dalam membentuk opini mereka. Hal tersebut dimungkinkan mengingat Provinsi Jabar merupakan salah satu Provinsi dengan wilayah terluas dan jumlah penduduk terbesar di Indonesia. Permasalahan yang akan diteliti adalah sejauhmana pemberitaan Pilgub Jabar 2013 di media online dalam membentuk opini mahasiswa Fakultas Komunikasi UNIGA Kabupaten Garut Provinsi Jabar?. Tujuan penelitian ini adalah untuk menganalisis pemberitaan Pilgub Jabar tahun 2013 di media online dalam membentuk opini mahasiswa. Teori yang dipakai sebagai dasar penelitian ini adalah teori Agenda Setting. Populasi adalah mahasiswa Fikom UNIGA Garut yang berjumlah 81 orang, teknik penarikan sampel adalah total sampel. Teknik pengumpulan data dilakukan secara studi literatur dan menggunakan kuesioner. Hasil penelitian menunjukkan bahwa pemberitaan Pilgub Jabar tahun 2013 di media online mampu membentuk opini mahasiswa tentang kandidat gubernur yang ikut
\end{abstract}


dalam pemilihan gubernur pada tahun 2013, melalui visi dan misi serta program kerja mereka. Hal tersebut ditandai dengan keyakinan, kemantapan, dan aksi responden pada saat Pilgub Jabar tahun 2013.

Kata kunci: pemberitaan Pilgub Jabar, media online, opini mahasiswa.

\section{PENDAHULUAN}

Saat ini peradaban manusia telah memasuki era baru, Alvin Toffler menyebutnya dengan The Third Wave atau gelombang ketiga, dikatakan bahwa fungsi informasi menjadi jauh lebih penting daripada era sebelumnya. Pada era baru ini, telah muncul media baru seperti internet. Rahardjo (2011) mengatakan bahwa keberadaan media baru tidak bisa dilepaskan dari perkembangan teknologi informasi dan komunikasi yang begitu pesat. Internet sebagai sebuah produk teknologi, meski sudah berkembang beberapa puluh tahun yang lalu, namun masih menjadi perbincangan publik hingga sekarang.

Pertumbuhan internet yang begitu pesat, disebabkan banyaknya fasilitas yang memudahkan orang untuk berkomunikasi dan mencari serta mendapatkan berbagai informasi dengan mudah dan cepat. Perkembangan media online di Indonesia tidak terlepas dari kebijakan yang telah digulirkan oleh pemerintah khususnya Kementerian Komunikasi dan Informatika RI untuk membangun sarana dan prasarana Teknologi Komunikasi dan Informatika (TIK). Kebijakan tersebut mengacu pada komitmen yang telah disepakati oleh wakil dari negara-negara dunia termasuk Indonesia, yang mengikuti Konverensi Tingkat Tinggi Dunia tentang Masyarakat Informasi / World Summit On The Information Society (WSIS) di Jenewa tahun 2003 dan Tunisia tahun 2005, yang mempunyai visi mewujudkan masyarakat informasi dan menghilangkan kesenjangan digital. Sementara di Indonesia visi Masyarakat Informasi Indonesia (MII) harus tercapai pada tahun 2015. Konsekuensi dari kesepakatan tersebut adalah menjadikan informasi bersifat bordeless di mana informasi bisa diakses siapapun, di manapun, tidak terbatas ruang dan waktu.

Pembangunan sarana dan prasaran TIK dilakukan agar masyarakat bisa mengakses informasi dengan cepat, mudah, dan murah. Termasuk di dalamnya informasi mengenai Pemilihan Gubernur (Pilgub). Perkembangan media online dalam ranah kehidupan sosial masyarakat, lambat laun akan menjadi sesuatu yang tidak terpisahkan dari aktivitas politik tanah air.

Di Indonesia, pemanfaatan media online termasuk di dalamnya media sosial di bidang politik mulai dilakukan pada Pemilihan Umum Legislatif (Pileg) tahun 2009, di mana pada saat itu merupakan Pemilu yang paling ramai diwarnai kampanye lewat media online. Untuk pertama kalinya, beberapa kandidat legislatif memiliki media sendiri yang dikelola secara virtual. Para caleg memiliki blog yang dibuat, baik oleh dirinya sendiri maupun oleh tim suksesnya. Isinya sangat beragam, ada yang menampilkan profil dirinya saja, ada juga yang dilengkapi dengan program-program atau janji-janji (Tabroni, 2012).

Pilgub Jawa Barat (Jabar) yang puncaknya jatuh pada tanggal 24 Februari 2013, menampilkan lima pasang calon. Empat pasang diusung oleh Partai Politik, yakni Ahmad Heryawan-Dedi Mizwar (PKS, Hanura, PPP, dan Partai Bulan Bintang), Dede Yusuf-Lex Laksamana (Partai Demokrat, PAN, PKB, dan Partai Gerindra), Rieke Diah Pitaloka-Teten Masduki (PDIP), Irianto MS Syafiuddin-Tatang Farhanul Hakim (Partai Golkar), dan satu pasang dari nonparpol yakni Dikdik Mulyana Arif Mansur-Cecep NS Toyib.

Pilgub Jabar kali ini merupakan Pilgub yang kedua kalinya dilaksanakan secara langsung. Jumlah pemilih tetap atau Daftar Pemilih Tetap (DPT) Pilgub Jabar tahun 2013 sesuai hasil rekapitulasi rapat pleno terbuka KPU Jabar ditetapkan sebanyak 32.536 .980 orang dan akan menyoblos di 74.948 TPS di 26 Kabupaten/ Kota di Jabar. Jumlah tersebut 
terdiri dari 16.382 .180 pemilih laki-laki dan 16.154.800 pemilih perempuan. Jumlah DPT tersebut bertambah sebanyak 2.353 orang dari Daftar Pemilih Sementara (DPS) yang diumumkan pada November 2012 lalu (Anonim, 2013).

Pemanfaatan media online dalam Pilgub Jabar tampaknya sangat cocok, mengingat Provinsi Jabar merupakan salah satu Provinsi dengan wilayah terluas dan jumlah penduduk terbesar di Indonesia. Para kandidat gubernur dan wakil gubernur Jabar yang akan bertanding dalam Pilgub Jabar tahun 2013 harus melakukan sosialisasi dan kampanye secara kreatif untuk menjangkau semua konstituen. Di samping itu jumlah pengguna internet di Jabar saat ini diperkirakan mencapai 10 juta orang. Dengan demikian media online diharapkan dapat menjadi media yang efektif dalam sosialisasi dan kampanye kemenangan kandidat pada Pilgub Jabar tahun 2013 (Rizal, 2012).

Media online merupakan media komunikasi yang efek terbesarnya adalah membentuk opini publik, jadi secara langsung maupun tidak langsung media online bisa memengaruhi cara berpikir bahkan tindakan seseorang yang mengonsumsinya. Opini publik bisa terbentuk dengan cara menyebarkan informasi secara berkala kepada publik atau masyarakat.

Berdasarkan uraian tersebut, maka peneliti tertarik untuk melakukan penelitian tentang pemberitaan Pilgub Jabar tahun 2013 di media online dalam membentuk opini mahasiswa. Penelitian ini dilakukan untuk menganalisis peran pemberitaan Pilgub Jabar tahun 2013 di media online dalam membentuk opini mahasiswa UNIGA di Kabupaten Garut Provinsi Jabar mengenai Pilgub Jabar tahun 2013.

UNIGA di Kabupaten Garut dipilih sebagai lokasi penelitian karena perguruan tinggi tersebut merupakan perguruan tinggi terbesar di Kabupaten Garut dan lokasinya tidak begitu jauh dengan daerah perkotaan. Berdasarkan pengamatan mereka juga telah banyak memanfaatkan media online sebagai sarana untuk mendapatkan berbagai informasi termasuk mengikuti pemberitaan mengenai Pilgub Jabar tahun 2013. Dengan demikian diharapkan mahasiswanya bisa memberikan tanggapannya tentang Pilgub Jabar tahun 2013.

Permasalahan yang akan dicari pemecahannya dalam penelitian adalah sejauhmana pemberitaan Pilgub Jabar tahun 2013 di media online dalam membentuk opini mahasiswa Fakultas Komunikasi UNIGA Kabupaten Garut Provinsi Jabar?, permasalahan tersebut dapat diidentifikasi sebagai berikut: (1) Sejauhmana penonjolan berita Pilgub Jabar tahun 2013 di media online dalam membentuk opini mahasiswa Fakultas Komunikasi UNIGA Kabupaten Garut Provinsi Jabar?; (2) Sejauhmana penyajian berita Pilgub Jabar tahun 2013 di media online dalam membentuk opini mahasiswa Fakultas Komunikasi UNIGA Kabupaten Garut Provinsi Jabar?; (3) Sejauhmana isi berita Pilgub Jabar tahun 2013 di media online dalam membentuk opini mahasiswa Fakultas Komunikasi UNIGA Kabupaten Garut Provinsi Jabar?;

Adapun tujuan penelitian ini adalah: (1) Ingin menganalisis penonjolan berita Pilgub Jabar tahun 2013 di media online dalam membentuk opini mahasiswa Fakultas Komunikasi UNIGA Kabupaten Garut Provinsi Jabar; (2) Ingin menganalisis penyajian berita Pilgub Jabar tahun 2013 di media online dalam membentuk opini mahasiswa Fakultas Komunikasi UNIGA Kabupaten Garut Provinsi Jabar; (3) Ingin menganalisis isi berita pemberitaan Pilgub Jabar tahun 2013 di media online dalam membentuk opini mahasiswa Fakultas Komunikasi UNIGA Kabupaten Garut Provinsi Jabar;

Kegunaan penelitian adalah:

Penelitian ini diharapkan memberi masukan kepada Ditjen Aptika Kementerian Kominfo mengenai sejauhmana penetrasi masyarakat khususnya mahasiswa di kota-kota kecil seperti Kabupaten Garut terhadap media online/internet; (2) Penelitian ini juga diharapkan dapat memberikan masukan kepada para kandidat/gubernur terpilih /tim sukses/siapapun untuk lebih kreatif dalam mengemas informasi dalam media online agar informasi apapun yang akan mereka sampaikan ke masyarakat diterima dan 
diakses oleh para pengguna internet, sehingga dapat memberikan citra yang baik bagi mereka.

\section{LANDASAN KONSEP}

\section{Kajian Pustaka}

Penelitian yang pernah dilakukan mengenai ampuhnya media massa dan media online dalam membentuk opini publik, pernah dilakukan oleh Amiruddin Z, penulis di Balai Besar Pengkajian dan Pengembangan Komunikasi dan Informatika Medan. Penelitian dengan judul "PERAN MEDIA DALAM PEMBENTUKAN OPINI MASYARAKAT DI WILAYAH PERBATASAN MENGENAI JATI DIRI BANGSA", mengungkap tentang peran media dalam pembentukan opini masyarakat di wilayah perbatasan mengenai jati diri bangsa Indonesia. Penelitian tersebut bersifat kualitatif, metode penelitiannya adalah deskriptif. Hasil penelitian terungkap bahwa wilayah perbatasan masih merupakan daerah tertinggal dari berbagai aspek, termasuk tentang keberadaan dan peran dari media nasional. Namun masyarakat lebih memilih memanfaatkan media dari Malaysia (televisi dan radio) dari negara tetangga Malaysia, karena media dari Malaysia lebih jelas dan mudah. Jati diri masyarakat di wilayah perbatasan ternyata tidak luntur, namun wawasan kebangsaan mereka dapat dikatakan menurun, hal tersebut tentu suatu kewajaran disebabkan minimnya penjelasan dan informasi dari tayangan atau siaran media nasional (Amiruddin, 2009).

Penelitian di atas hanya membahas bagaimana peran media konvensional dalam membentuk opini masyarakat di wilayah perbatasan. Apakah media massa konvensional cukup berperan dalam membentuk opini masyarakat mengenai jati diri bangsa. Sementara saat ini teknologi komunikasi dan informasi telah berkembang begitu pesat, sehingga memunculkan media baru seperti internet. Kehadiran internet telah memengaruhi seluruh kehidupan manusia, dengan memberikan berbagai kemudahan, serta menjadi sumber informasi bagi siapapun.

Kemudian kajian mengenai "PERAN MEDIA ONLINE DALAM MEMBENTUK OPINI PUBLIK PADA KASUS ARGA TIRTA KIRANA", yang ditulis oleh Dewi Kartika Sari, dosen Ilmu Komunikasi Universitas Kristen Satya Wacana (UKSW) Salatiga. Kajian ini mengupas tentang kasus Arga Tirta Kencana dan kasus Prita Mulyasari, mereka masing-masing menulis dalam blognya dan melalui email menyampaikan keluh kesah yang mereka rasakan kurang adil. Tulisan mereka akhirnya mendapat tanggapan dari publik dan mereka memperoleh dukungan publik melalui media online atau internet. Selanjutnya dibahas bahwa internet dianggap menyuarkan kepentingan publik dan "bebas" dari intervensi ideologi individu atau sekelompok orang tertentu, sehingga internet dianggap dapat mewakili suara individu atau publik. Dengan menggunakan media online sebagai alat penyampai saran, kritik, protes, curhat, maka publik dapat menggunakan internet sesuai dengan kebutuhan publik. Teori Agenda Setting digunakan untuk mengupas kajian ini. Kajian yang dilakukan oleh Dewi Kartika Sari di atas dilakukan melalui pengamatan terhadap berita-berita atau informasi-informasi yang ditulis di media online (Sari, 2011).

Sementara dalam penelitian mengenai "Pemberitaan pemilihan Gubernur Jabar 2013 di Media Online dalam Membentuk Opini Mahasiswa", yang dilakukan oleh peneliti akan mengupas mengenai sejauhmana peran media online dalam membantuk opini mahasiswa pada Pilgub Jabar tahun 2013. Di era konvergensi media online menjadi media yang tidak dapat dipisahkan dari aktivitas politik. Terbukti sudah banyak politikus/kandidat dalam Pilpres yang memenangkan pemilihan dengan memanfaatkan media online sebagai media untuk menyosialisasikan berbagai program yang diusung oleh kandidat dan juga menjadi sarana untuk memperkenalkan diri mereka ke khalayak. Penelitian dilakukan menggunakan pendekatan deskriptif kuantitatif. 


\section{Kerangka Pemikiran}

Sekilas tentang Pemilihan Gubernur Jabar (Pilgub Jabar) Tahun 2013

Pilgub Jabar yang telah berlangsung pada tanggal 24 Februari 2013 lalu, diikuti oleh lima pasang kandidat gubernur dan wakil gubernur yakni Ahmad Heryawan - Deddy Mizwar, Dede Yusuf Effendy - Lex Laksmana, Rieke Diah Pitaloka - Teten Masduki, Irianto MS Syafiuddin - Tatang Farhanul Hakim, dan Dikdik Mulyana Arief Mansur - Cecep Nana Suryana Toyib.

Pemberitaan mengenai Pilgub Jabar tahun 2013 telah mewarnai media online. Berbagai situs mulai dari situs pribadi hingga situs surat kabar online banyak memberitakan mengenai hal tersebut. Bahkan di era konvergensi saat ini, masing-masing pasangan selain memanfaatkan media massa konvensional untuk memperkenalkan diri mereka maupun program-program yang mereka usung, mereka juga memanfaatkan kehadiran media baru yang saat ini lebih terkenal dengan nama media online. Melalui media tersebut mereka berharap dapat menjaring suara lebih banyak karena media tersebut dapat menjadi ajang sosialisasi dan bahkan menjadi alat untuk berinteraksi langsung dengan calon pemilih.

Di Indonesia akses teknologi informasi dan komunikasi seperti telepon, handphone (HP), dan internet sudah cukup tinggi. Khusus untuk pengguna internet berdasarkan survei dari internetworldstats.com pada tahun 2010, jumlah pengguna internet Indonesia menempati urutan ke-16, dengan jumlah pengguna internet 30 juta pengguna. Padahal, populasi penduduk Indonesia berdasarkan survei tahun 2010, berjumlah sekitar 142 juta. Berarti jumlah pengguna internet di Indonesia baru sekitar 21,1\% yang sudah menggunakan internet (Ceritarara, 2012).

Bisa dibayangkan, masih ada 79,9\% penduduk atau 112 juta penduduk yang belum menggunakan internet. Walaupun begitu, Indonesia menempati urutan ke-4 di Asia, dan urutan pertama di Asia Tenggara sebagai negara dengan jumlah pengguna internet terbanyak. Kemajuan yang bisa dibilang cukup pesat selama 10 tahun terakhir. Pada tahun 2000, pengguna internet di Indonesia hanya 2 juta pengguna, dalam waktu 10 tahun meningkat menjadi 30 juta pengguna di tahun 2010, dan pada tahun 2011 terdapat 39,6 juta pengguna internet. Khusus Jabar pengguna internet saat ini diperkirakan berjumlah 10 juta orang (Rizal, 2012).

Penggunaan media online sebagai sarana sosialisasi dan ajang kampanye kandidat gubernur merupakan cara yang cukup ampuh untuk menjaring suara konstituen, karena selain pengguna internet di Jabar yang saat ini jumlahnya cukup banyak, Jabar juga merupakan salah satu Provinsi dengan wilayah terluas dan jumlah penduduk terbesar di Indonesia, sehingga media tersebut dianggap cukup efektif untuk menjaring konstituen.

\section{Media Online}

Perkembangan teknologi komunikasi dan informasi saat ini sudah sangat pesat. Terlihat dari munculnya media online seperti internet. Internet menawarkan begitu banyak kemudahan-kemudahan melalui fasilitasfasilitas yang dimilikinya, sehingga berbagai informasi dapat diterima dengan sangat cepat. Teknologi internet ditemukan menjelang abad ke-21 di saat jatuhnya pemerintah komunis Uni Soviet, serta merebaknya paham demokrasi di Eropa Timur, termasuk Rusia dan kawasan Asia. Oleh karenanya, menurut Cangara dalam Tabroni (2012), para teknolog idealis yang mengembangkan internet yakin bahwa kehadiran media ini dengan cepat akan menyebarluaskan nilai-nilai baru untuk memperkuat demokrasi ke seluruh dunia, terutama dalam membangun pemerintahan yang lebih trasparan. Internet sendiri merupakan singkatan dari international networking atau interconnection networking yang berarti sebuah jaringan komputer global yang menghubungkan jutaan komputer di seluruh dunia sehingga setiap komputer yang terkoneksi di dalamnya dapat berkomunikasi atau bertukar data tanpa dibatasi jarak, waktu, dan tempat (LaQuay, 1997). Internet juga bisa dipandang seperti sebuah kota elektronik yang sangat besar di mana setiap penduduknya memiliki alamat (internet 
address) yang dipakai untuk bertukar informasi. Ia merupakan gudang informasi tanpa batas, sebagai database atau perpustakaan multimedia yang sangat besar dan lengkap, bahkan internet dianggap duplikasi nyata hanya disajikan dalam bentuk maya.

Media online adalah sebutan umum untuk sebuah bentuk media yang berbasis telekomunikasi dan multimedia (komputer dan internet). Di dalamnya terdapat portal, website (situs web), radio-online, televisionline, pers online, mail-online, dan lain-lain, dengan karakteristik masing-masing sesuai dengan fasilitas yang memungkinkan user memanfaatkannya.

Media online yang saat ini populer di Indonesia adalah website termasuk di dalamnya adalah media sosial seperti facebook, twitter, blog, online forum, online news, dan youtube.

Penggunaan media online oleh kandidat Pilgub Jabar tahun 2013 dalam menggalang suara masyarakat, telah dilakukan sejak dimulainya proses Pilgub. Sementara itu media online yang digunakan meliputi situs, jejaring sosial seperti facebook, twitter, dan blog.

Segala aktivitas calon gubernur Jabar tersebut diinformasikan di media online. Konten yang menarik akan disebarkan oleh para netizen secara sukarela melalui blog, facebook, dan twitter atau forum secara sukarela. Percakapan dan rekomendasi netizen di media sosial lebih dipercaya oleh social networknya, daripada percakapan yang dilakukan oleh kandidat dan tim sukses sendiri (Rizal, 2012).

Media online temasuk di dalamnya media sosial dan jejaring sosial dari para kandidat tersebut merupakan media untuk menyampaikan dan menginformasikan atau menyosialisakan pada para netizen mengenai profil, visi dan misi, program-program para kandidat, kampanye kandidat, dan lain-lain. Disamping itu media tersebut merupakan media yang dapat dimanfaatkan oleh masyarakat untuk lebih mengenal sosok dari masing- masing kandidat.

\section{Pembentukan Opini Publik}

Opini publik merupakan terjemahan dari kosa kata bahasa Inggris yakni public opinion. Ditinjau dari sudut asal katanya (etymology), Public Opinion berasal dari bahasa Latin yakni opinari dan publicus. Opinari berarti berpikir atau menduga. Publicus berarti milik masyarakat luas (Yesicha, 2011).

Bryce dalam Nimmo (2005), menyebutkan bahwa opini publik adalah kumpulan pendapat orang mengenai hal ihwal yang memengaruhi atau menarik minat komunitas. Nimmo mengatakan bahwa semua opini mencerminkan suatu organisasi yang kompleks yang terdiri dari 3 (tiga) komponen:

1. Keyakinan: seseorang yang memiliki keyakinan tentang suatu hal akan memiliki persepsi tentang suatu hal tersebut. Keyakinan berkaitan erat dengan aspek kognitif. Menyangkut percaya atau tidak terhadap suatu hal.

2. Nilai: preferensi yang dimiliki seseorang untuk tujuan tertentu. Nilai berkaitan erat dengan aspek afektif. Menyangkut perasaan suka atau tidak suka terhadap suatu hal.

3. ekspektasi: seseorang mengonstruksikan tindakan dengan membawa pengalaman masa lalu untuk digunakan pada saat ini dalam rangka mengakses kemungkinan pada masa yang akan datang. Ekspektasi berkaitan erat dengan aspek konatif (kecenderungan).

Pembentukan opini mahasiswa berkaitan dengan Pilgub Jabar tahun 2013, dimulai dari berkembangnya pemberitaan di berbagai media termasuk media online. Berita-berita atau informasi yang berkembang memunculkan pendapat dalam diri individu atau dalam kelompok (mahasiswa). Interaksi di antara mereka dan pendapat-pendapat yang mereka kemukakan, ditambah berbagai pengalaman yang telah mereka alami, akan memunculkan opini mereka.

Jika dikaitkan dengan Pilgub Jabar tahun 2013, maka berita-berita atau informasi-informasi yang berkembang mengenai proses Pilgub Jabar di media online 
akan berlanjut menjadi opini dari para individu. Opini-opini individu tersebut akan berkembang menjadi suatu konsensus bila masyarakat dalam segmen tertentu mempunyai kesamaan-kesamaan tertentu. Individu-individu dalam lingkungan kampus pasti mempunyai kesamaan-kesamaan dalam hal pemikiran dan pandangan-pandangan mereka tentang calon pemimpin Jabar. Proses pembentukan opini itu sendiri melalui beberapa tahap seperti keyakinan, penilaian, dan kecenderungan.

\section{Teori Agenda Setting}

Teori Agenda Setting pertama kali dikemukakan oleh Walter Lippman (Rakhmat, 2005). Maxwell McCombs dan Donald Shaw, mengemukakan asumsi dasar dari teori Agenda Setting, yakni adanya hubungan yang positif antara penilaian yang diberikan media pada suatu persoalan dengan perhatian yang diberikan khalayak pada persoalan itu.

Model Agenda Setting dapat digambarkan, seperti terlihat pada gambar 1 .

Pemberitaan mengenai proses Pilgub Jabar tahun 2013 di media online masuk dalam arena penentuan isu publik. Pemberitaan tersebut diarahkan agar publik dapat mengetahui dan memahaminya, dan pada akhirnya menumbuhkan opini publik. Pemilihan isu tersebut dikenal dengan agenda setting. Cutlip, Center dan Broom (2000) menyatakankonsekuensi-konsekuensi agenda setting media. Konsekuensi tersebut adalah:

1. Pertama, pemberitaan media dapat mengangkat isu-isu publik, orang-orang, organisasi-organisasi, institusi-institusi, dan sebagainya.

2. Kedua, perubahan perhatian yang besar pada media dapat membawa perubahan pada prioritas publik.

3. Ketiga, semakin masyarakat peduli terhadap sesuatu, semakin mereka ingin mempelajarinya, semakin kuat opini mereka, dan semakin mereka ingin melakukan tindakan tertentu atas isu tersebut.

4. Keempat, pemberitaan media dapat memengaruhi prioritas-prioritas pada publik spesifik dan publik penting seperti legislator, regulator, dan pembuat kebijakan lain.

Sesuai dengan teori Agenda Setting yang penulis gunakan sebagai landasan dari penelitian ini, maka kerangka teoretisnya dapat digambarkan pada gambar 2 .

\section{METODE PENELITIAN}

Pendekatan penelitian ini adalah deskriptif kuantitatif dengan menggunakan metode survei yaitu suatu upaya mengumpulkan informasi dari responden dengan menggunakan kuesioner. Dalam hal ini, kuesioner digunakan sebagai instrumen utama pengumpul data penelitian. (Singarimbun, 1989).

Populasi dalam penelitian ini adalah mahasiswa Fakultas Komunikasi jurusan Humas dan Jurnalistik di UNIGA angkatan 2011 yang berusia antara 18 tahun hingga 23 tahun. Jumlah keseluruhan populasi 81 orang. Penentuan sampel dilakukan dengan total sampel karena jumlah populasi hanya sedikit sehingga peneliti memutuskan untuk mengambil seluruh populasi sebagai sampel.

Pengumpulan data dilakukan dengan menggunakan kuesioner yaitu memberikan seperangkat daftar pertanyaan pada responden, sebagai data primer. Sementara data sekunder adalah data berupa dokumen, catatan, laporan, dan lain sebagainya, oleh karenanya untuk mendapatkan informasi dari data sekunder, penulis menggunakan teknik pengumpulan data dengan menelusuri catatan-catatan, laporan, dokumen, dan sebagainya.

Pengolahan data hanya dilakukan terhadap responden yang mengisi kuesioner secara lengkap. Pengolahan data dilakukan dengan cara: editing, dilakukan dengan cara pengecekan atau mengoreksi data yang telah terkumpul untuk menghindari data yang meragukan atau tidak logis. Entry data, memasukan data dari angket melalui program SPSS. Tabulasi, menyusun data yang telah diberi kode ke dalam tabel, untuk analisis data selanjutnya. 


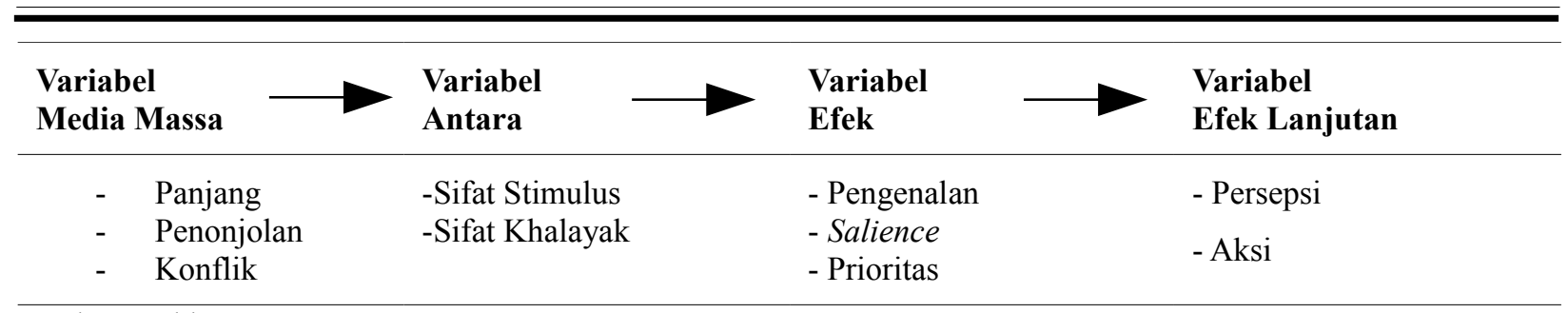

Sumber: Rakhmat, 2005.

\section{Gambar 1 \\ Model "Agenda Setting"}

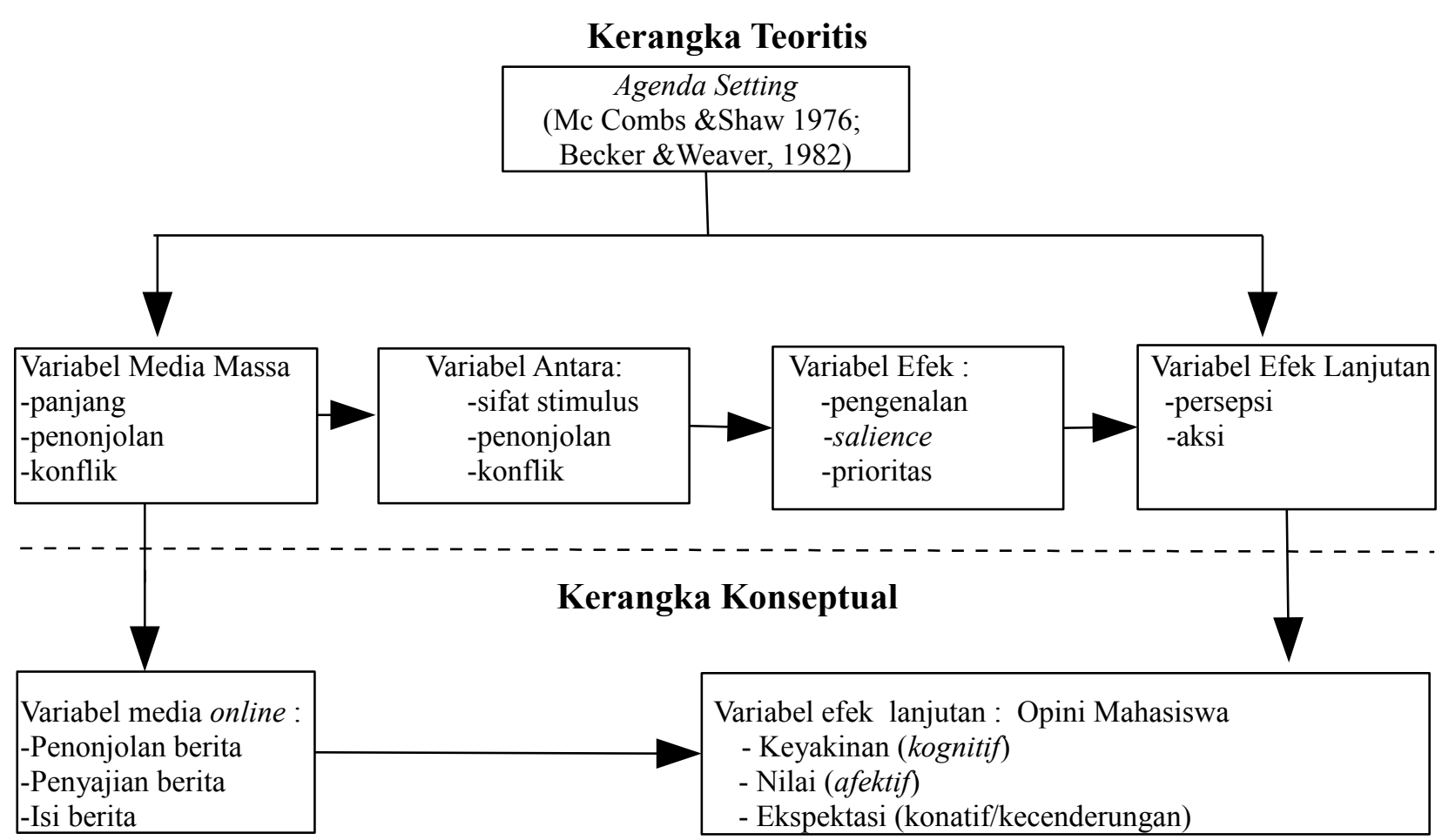

(Sumber : pemikiran penulis)

\section{Gambar 2 \\ Model Penelitian}

Analisis data dilakukan secara deskriptif yakni untuk memperoleh gambaran umum mengenai variabel-variabel yang diteliti. Melalui analisis deskriptif peneliti berusaha memaparkan data atau jawaban yang diberikan oleh responden pada kuesioner yang telah disusun atas beberapa pertanyaan yang relevan dengan penelitian. Hasil jawaban tersebut akan dimuat dalam bentuk tabel tunggal dan silang, sehingga diharapkan memberikan gambaran yang jelas mengenai masalah penelitian.

\section{HASIL PENELITIAN DAN PEMBAHASAN}

\section{Hasil Penelitian}

Karakteristik atau identitas responden

Jumlah sampel dalam penelitian ini adalah 81 orang mahasiswa Fikom UNIGA angkatan 2011, yang terdiri dari 56 orang mahasiswa jurusan humas atau public relation dan 25 orang mahasiswa jurusan Jurnalistik. Namun dari 81 angket yang disebarkan ke responden ternyata hanya 77 angket yang layak untuk dianalisis dan 
memenuhi syarat untuk diikutsertakan dalam pembahasan selanjutnya, sedangkan 4 angket dinyatakan tidak layak karena kekuranglengkapan dalam pengisian kuesioner.

Usia responden dalam penelitian ini berkisar antara 18 tahun hingga 21 tahun, namun yang terbanyak adalah responden usia 19 tahun yang berjumlah 33 orang $(42,9 \%)$ dan usia 20 tahun yang berjumlah 29 tahun $(37,7 \%)$. Rentang usia $18-21$ bisa dikategorikan ke dalam tahap usia remaja akhir. Sementara pemilih, mereka masuk dalam kategori pemilih pemula. Sebagai remaja mereka sudah cukup mengenal media online termasuk di dalamnya media sosial, seperti facebook dan twitter serta memanfaatkan perkembangan tersebut untuk memenuhi keingintahuan mereka akan berbagai hal termasuk proses Pilgub Jabar tahun 2013. Di beberapa wilayah di Indonesia, para kandidat dalam Pilkada sudah banyak yang menggunakan media online untuk menyosialisasikan diri pada masyarakat. Hal terjadi karena memang media online sudah cukup dikenal di masyarakat khususnya kaum remaja.

Rentang usia 18 - 21 tahun juga bisa dikategorikan sebagai remaja, mereka sudah tidak asing lagi dengan media online, hal tersebut dibuktikan dari hasil penelitian, di mana semua responden sudah cukup mengenal media online. Bahkan dalam berbagai aktivitasnya, responden tidak terlepas dari media online, baik untuk keperluan berkomunikasi, berinteraksi, mencari informasi maupun aktivitas lainnya, termasuk aktivitas dalam mencari informasi mengenai Pilgub Jabar tahun 2013.

Kemajuan TIK juga mendorong tumbuhnya berbagai peralatan canggih yang bisa digunakan untuk berselancar di dunia maya, seperti handphone misalnya. Handphone sudah menjadi barang yang wajib dimiliki oleh siapapun termasuk responden. Dari 77 responden, 67 responden $(40,36 \%)$ menyatakan memanfaatkan handphone tidak saja untuk berkomunikasi tetapi juga untuk berselancar di dunia maya. Seperti halnya komputer/laptop, saat ini handphone tidah hanya sebagai alat komunikasi saja namun sudah dirancang seperti halnya perangkat TIK lainnya (komputer/laptop).

\section{Pemberitaan Pilgub Jabar Tahun 2013 di Media online dan Pembentukan Opini Mahasiswa \\ Terpaan Media}

Kecanggihan peralatan sebagai produk dari kemajuan TIK telah memudahkan seseorang untuk melakukan aktivitas kesehariannya. Banyak sekali informasi bisa didapatkan di dunia maya atau yang saat ini sering disebut dengan media online. Di ranah politik, pemberitaan mengenai Pilgub Jabar tahun 2013 telah menjadi agenda media, yakni untuk menginformasikan segala peristiwa yang menyangkut Pilgub/proses Pilgub kepada publik. Termasuk juga proses Pilgub Jabar tahun 2013, pemberitaannya bisa didapatkan dengan mudah dan cepat di berbagai situs di media online.

Dari sekian banyak jenis berita atau informasi di media online, tampaknya berita politik masih disukai oleh responden. Hal tersebut terlihat dari hasil penelitian, di mana 50 responden $(15,92 \%)$ menyatakan bahwa berita politik merupakan jenis berita yang sering diakses oleh responden, bahkan 29 responden $(37,7 \%)$ menyatakan selalu mengikuti pemberitaan proses Pilgub Jabar tahun 2013 di media online. Hal ini tentunya sangat menggembirakan, sebagai generasi muda mereka masih peduli dengan proses demokratisasi yang sedang berlangsung seperti Pilgub.

Sementara frekuensi yang digunakan untuk mengakses pemberitaan Pilgub Jabar tahun 2013 di media online tersebut masih rendah. Hasil penelitian memperlihatkan, hanya 5 responden $(6,5 \%)$ yang mengikuti pemberitaan Pilgub Jabar tahun 2013 setiap hari dan 24 responden $(31,2 \%)$ menyatakan mengiktui pemberitaan Pilgub Jabar tahun 2013 setiap dua hari sekali. Selebihnya mengikuti pemberitaan Pilgub Jabar tahun 2013 tiap empat, lima, dan enam hari sekali. Patut diapresiasi karena di tengah-tengah aktivitas responden yang cukup padat sebagai seorang mahasiswa mereka masih meluangkan cukup waktu untuk mengikuti 
proses Pilgub Jabar tahun 2013. Kepedulian responden terhadap berita politik khususnya pemberitaan Pilgub Jabar tahun 2013, karena berkaitan dengan akan dipilihnya calon pemimpin Jabar.

Jenis informasi Pilgub Jabar tahun 2013 yang mereka ikuti di media online antara lain adalah visi dan misi kandidat, profil kandidat, program kerja kandidat, dan kegiatan kampanye kandidat. Beberapa responden juga mengikuti semua pemberitaan yang bersangkut paut dengan aktivitas kandidat gubernur yang diberitakan di media online, seperti situs surat kabar online, maupun situs pribadi kandidat dan media sosial. Selain mengikuti pemberitaan di berbagai situs, 10 responden $(13 \%)$ dari 77 responden mengaku memanfaatkan media sosial seperti twitter untuk berkomunikasi dan berinteraksi secara langsung dengan kandidat gubernur.

\section{Penonjolan Berita Pilgub Jabar 2013 di Media Online}

Frekuensi pemunculan berita/informasi merupakan stimulus yang memengaruhi respons, dalam hal ini selektivitas kognisi. Krech dalam Yuniati (2002) mengatakan, "Suatu pesan yang sering diulang-ulang, akan lebih menarik perhatian seseorang daripada pesan yang kurang banyak diungkapkan". Tan dalam Yuniati (2002), menyebutkan hasil penelitian Zajonc dan kawan-kawan, pengulangan terpaan pesan efektif tidak saja untuk menarik perhatian, tetapi juga dalam menentukan pilihan komunikan terhadap suatu objek.

Di era konvergensi, pemberitaan mengenai Pilgub Jabar tahun 2013 tidak hanya mendominasi media massa konvensional saja. Media online tampaknya juga banyak memunculkan pemberitaan/informasi politik seperti Pilgub Jabar tahun 2013. Tidak hanya sebatas pemberitaan, namun para kandidat sendiri juga memanfaatkan media online untuk mempromosikan dirinya sendiri dengan membuat situs pribadi dan membuka akun baik di facebook, twitter, maupun blog. Hal tersebut dilakukan agar para kandidat dapat secara langsung berkomunikasi dan berinteraksi dengan calon pemilih.

Pemunculan berita/informasi mengenai Pilgub Jabar tahun 2013 di media online yang berulang-ulang, dianggap cukup efektif untuk menggalang suara calon pemilih, terutama bagi pemilih pemula atau generasi muda. Untuk mengangkat pentingnya sebuah isu dalam benak publik media perlu mengangkat berita yang diulang-ulang. Hal tersebut merupakan fungsi penentuan agenda (agenda setting function) di mana media mempunyai kemampuan untuk mengangkat berita yang diulang-ulang (Severin dan Tankard, 2007).

Hasil penelitian menunjukkan bahwa frekuensi pemunculan berita/informasi mengenai Pilgub Jabar tahun 2013 di media online memang cukup sering, hal tersebut terungkap dari pendapat 59 responden $(76,6 \%)$ yang menyatakan bahwa media online mengangkat semua aktivitas kandidat selama proses Pilgub berlangsung. Namun pemberitaan mengenai kandidat yang populer dan sudah familiar yang paling sering diikuti oleh responden. Bagi mereka segala sesuatu yang memberitakan mengenai artis, menarik perhatian untuk diikuti. Seperti dikatakan oleh pasangan independen Dikdik-Cecep, sebetulnya nama dan aktivitas mereka sudah sering muncul baik di media lokal Jabar maupun di media online serta media sosial, namun nama mereka tenggelam oleh namanama besar dari Jakarta dan kalangan artis. Sehingga yang banyak diingat dan dikenal orang adalah nama-nama artis dan calon incumbent saja.

Pemberitaan mengenai Pilgub Jabar tahun 2013 cukup mendominasi media online, hal tersebut dikemukakan oleh 69 responden $(89,7 \%)$. Dominasi pemberitaan mengenai Pilgub Jabar tahun 2013 di media online, merupakan salah satu dari agenda setting media. Ketika sebuah berita masuk dalam media dan diberitakan secara berulangulang maka hal tersebut sudah merupakan agenda setting dari media. Media menganggap bahwa isu Pilgub Jabar merupakan isu penting yang harus diberitakan, media juga menganggap bahwa isu Pilgub Jabar mempunyai nilai yang 
penting untuk diberitakan dan diketahui oleh publik. Sehingga pemberitaannya terus muncul dalam berbagai media.

Seperti yang dikemukakan oleh Lang dan Lang dalam Severin dan Tankard (2007):

"Media massa memaksakan perhatian pada isu-isu tertentu. Media massa membangun citra publik tentang figurfigur politik. Media massa secara konstan menghadirkan objek-objek yang menunjukkan apa yang hendaknya dipertimbangkan, diketahui, dan dirasakan individu-individu dalam masyarakat".

Agenda setting berlaku pada pemberitaan Pilgub Jabar tahun 2013 di media online. Beberapa konsekuensi yang muncul akibat agenda setting tersebut menurut Cutlip, Center dan Broom dalam Sari (2011) adalah: pertama, pemberitaan di media online, dapat mengangkat isu-isu publik, orang-orang, organisasi-organisasi, institusi-institusi, dan sebagainya. Kedua, perubahan perhatian yang besar pada media dapat membawa perubahan pada prioritas publik. Ketiga, semakin masyarakat peduli terhadap sesuatu, semakin mereka ingin mempelajarinya, semakin kuat opini mereka, dan semakin mereka ingin melakukan tindakan tertentu atas isu tersebut. Keempat, pemberitaan media dapat memengaruhi prioritas-prioritas pada publik spesifik dan publik penting seperti legislator, regulator, dan pembuat kebijakan lain.

Isu-isu Pilgub Jabar tahun 2013 telah diangkat dan pemberitaannya sangat menonjol di media online. Pemberitaan Pilgub Jabar tahun 2013 tidak hanya memberitakan salah satu pasangan saja, namun kelima pasangan kandidat dengan berbagai aktivitasnya sangat menonjol di media online.

\section{Penyajian Berita Pilgub Jabar Tahun 2013 di Media Online}

Penyajian berita yang menarik merupakan salah satu dari agenda setting media juga, agar berita tersebut selalu dibaca oleh khalayak. Semakin sering berita di baca maka pembaca akan semakin mengingat apa yang dibacanya sehingga menambah pengetahuan dan pemahaman pembaca. Penyajian berita yang menarik juga akan berdampak pada perhatian seseorang terhadap suatu pemberitaan, hal ini tentunya akan menjadi prioritas seseorang untuk terus mengikuti pemberitaannya.

Tabel 1

\section{Pendapat Responden Mengenai Keistimewaan Pemberitaan Pilgub Jabar Tahun 2013 di Media Online}

\begin{tabular}{|c|c|c|c|}
\hline No & Uraian & $\mathbf{F}$ & $\%$ \\
\hline 1. & $\begin{array}{l}\text { Informasi atau pemberitaan mengenai Pilgub Jabar tahun } 2013 \text { dapat dengan mudah dan } \\
\text { cepat di dapat }\end{array}$ & 37 & 48,1 \\
\hline 2. & $\begin{array}{l}\text { Untuk mendapatkan informasi atau berita mengenai Pilgub Jabar tahun } 2013 \text { tidak } \\
\text { memerlukan biaya dan dapat diakses di mana saja, kapan saja. }\end{array}$ & 11 & 14,3 \\
\hline 3. & Melalui media online bisa berinteraksi langsung dengan kandidat gubernur. & 13 & 16,9 \\
\hline 4. & $\begin{array}{l}\text { Seseorang tidak akan ketinggalan informasi atau berita Pilgub Jabar tahun 2013, karena } \\
\text { tersedia setiap saat. }\end{array}$ & 16 & 20,8 \\
\hline \multicolumn{2}{|c|}{ Jumlah : } & 77 & 100 \\
\hline
\end{tabular}

Sumber: hasil penelitian. 
Salah satu hal yang istimewa dari penyajian berita Pilgub Jabar tahun 2013 di media online adalah kecepatan dan kemudahan dalam mencari informasi dan berita. Dalam hitungan detik responden bisa mendapatkan berbagai informasi yang diinginkannya di media online. Data mengenai hal tersebut tersaji dalam tabel 1 .

Kecepatan dan kemudahan mendapatkan informasi dan berita tentang Pilgub Jabar tahun 2013 di media online menjadi pilihan utama 37 responden $(48,1 \%)$, mengapa pemberitaan tentang Pilgub Jabar tahun 2013 dianggap istimewa. Selain kecepatan dan kemudahan yang membuat responden mengikuti pemberitaan Pilgub Jabar tahun 2013 di media online, juga karena media online sangat identik dengan generasi muda/anak-anak muda. Responden tidak harus mengeluarkan biaya untuk mendapatkan informasi tersebut, informasi tersaji setiap saat di media online.

Penyajian berita mengenai Pilgub Jabar tahun 2013 yang menarik di media online, juga membuat responden tertarik untuk selalu mengikuti pemberitaan tersebut. Hal ini terungkap dari hasil penelitian di mana 49 responden $(63,6 \%)$ menyatakan penyajian berita Pilgub Jabar tahun 2013 cukup menarik untuk dibaca dan diikuti, dan 3 responden (3,9\%) menyatakan sangat menarik. 23 responden $(29,9 \%)$ menyatakan kurang menarik dan 2 responden $(2,6 \%)$ menyatakan tidak menarik. Alasan yang dikemukakan oleh responden yang menyatakan penyajian pemberitaan Pilgub Jabar tahun 2013 sangat dan cukup menarik adalah bahwa di setiap pemberitaan selalu disediakan tempat untuk memberikan komentar terhadap pemberitaan tadi. Sementara itu pemberitaan di masingmasing situs/blog kandidat disertai dengan gambar atau aktivitas kandidat selama proses Pilgub berlangsung, serta ada tempat untuk bisa berinteraksi langsung dengan kandidat selain itu responden juga bisa memberikan komentar/saran/kritikan terhadap berita yang disajikan di situs media online. Hal tersebut sangat berbeda dengan sajian berita Pilgub Jabar tahun 2013 di media massa konvensional seperti surat kabar dan televisi, yang belum memberikan ruang untuk berinteraksi langsung dengan kandidat gubernur kecuali pada acara debat kandidat yang saat ini marak ditayangkan di televisi, namun itupun dibatasi oleh waktu.

Hasil penelitian juga menemukan bahwa tampilan berita di masing-masing situs pribadi, di antara lima kandidat gubernur Jabar yang bertarung di Pilgub Jabar tahun 2013 yang paling menarik adalah tampilan berita di situs kandidat Ahmad Heryawan. Hal tersebut diungkapkan oleh 26 responden $(33,8 \%)$, sementara itu 25 responden $(32,5 \%)$ menyatakan tampilan berita di situs kandidat Rieke Diah Pitaloka paling menarik, dan 15 responden $(19,5 \%)$ menyatakan tampilan berita di situs kandidat Dede Yusuf paling menarik. Sisanya 6 responden $(7,8 \%)$ menyatakan tampilan berita di situs kandidat Irianto paling menarik dan 5 responden $(6,4 \%)$ menyatakan tampilan berita di situs kandidat Dikdik paling menarik. Seperti telah dikemukakan di atas bahwa kandidat incumbent dan kandidat dari kalangan artis masih menjadi daya tarik masyarakat. Bagaimanapun mereka sudah cukup dikenal masyarakat.

\section{Isi Pemberitaan Pilgub Jabar Tahun 2013 di Media Online}

Isi pemberitaan mengenai Pilgub Jabar tahun 2013, akan berpengaruh terhadap pengetahuan dan pemahaman responden mengenai sosok para kandidat gubernur. Pengetahuan dan pemahaman tersebut pada akhirnya akan menguatkan opini mereka dan kecenderungan mereka untuk menentukan pilihannya.

Di antara sekian banyak pemberitaan Pilgub Jabar yang mendominasi media online, ternyata profil kandidat gubernur, visi dan misi, serta program-program yang ditawarkan kandidat merupakan pemberitaan yang isinya cukup menarik responden, karena melalui profil, visi dan misi, programprogram, tersebut seseorang akan mengetahui siapa sosok kandidat tersebut, bagaimana sepak terjangnya dalam berbagai organisasi, bagaimana kandidat tersebut akan 
Tabel 2

Pendapat Responden mengenai Isi Profil, Visi dan Misi, serta Program-Program Kandidat dalam Pilgub Jabar Tahun 2013 yang Paling Menarik di Media Online

\begin{tabular}{llcc}
\hline No & \multicolumn{1}{c}{ Uraian } & F & \% \\
\hline 1. & Profil pasangan Aher-Deddy & 29 & 37,7 \\
2. & Profil pasangan Rieke-Teten & 18 & 23,4 \\
3. & Profil pasangan Dede-Lex & 14 & 18,2 \\
4. $\quad$ Profil pasangan Dikdik-Cecep & 6 & 7,8 \\
5. $\quad$ Profil pasangan Irianto-Tatang & 10 & 13 \\
\hline Jumlah : & $\mathbf{7 7}$ & $\mathbf{1 0 0}$ \\
\hline
\end{tabular}

Sumber : Hasil Penelitian

Membangun Jabar untuk lima tahun ke depan, demikian dikemukakan oleh 42 responden $(54,5 \%)$, sementara sisanya yakni 35 responden $(45,5 \%)$ menyatakan bahwa isi pemberitaan mengenai kegiatan kampanye kandidat adalah yang paling menarik.

Di antara kelima pasangan kandidat ternyata profil, visi dan misi, serta programprogram kerja pasangan kandidat Ahmad Heryawan dan Deddy Mizwar, paling menarik, demikian dikemukakan oleh 29 responden $(37,7 \%)$. Isi visi dan misi serta program kerjanya menurut responden paling cocok untuk diterapkan untuk masyarakat Jabar. Salah satu point dari visi dan misi pasangan Aher-Deddy yang membuat menarik menurut responden adalah "mengokokohkan kehidupan sosial kemasyarakatan melalui peningkatan peran pemuda, olah raga, seni, budaya, dan kearifan lokal". Menurut responden karena pasangan tersebut mengedapankan peran pemuda, sehingga sangat cocok dengan responden yang tentunya adalah sebagai generasi muda. Data secara keseluruhan dapat dilihat pada tabel 2.

Meskipun demikian, responden berpendapat, baik isi pemberitaan Pilgub Jabar tahun 2013 di media online maupun isi profil, visi dan misi, serta program-program kandidat dalam Pilgub Jabar tahun 2013 sangat menarik demikian diungkapkan 7 responden $(9,1 \%), 37$ responden $(48 \%)$ menyatakan cukup menarik, 33 responden $(42,8 \%)$ menyatakan kurang menarik.

\section{Pembentukan Opini Mahasiswa \\ Keyakinan Mahasiswa}

Pemberitaan mengenai Pilgub Jabar tahun 2013 yang muncul secara terusmenerus di media online, cukup berperan dalam membentuk opini responden. Bryce dalam Nimmo (2005) menyebutkan bahwa opini publik adalah kumpulan pendapat orang mengenai hal ihwal yang memengaruhi atau menarik minat komunitas. Nimmo mengatakan bahwa semua opini mencerminkan suatu organisasi yang kompleks yang terdiri dari 3 komponen: (1) Keyakinan; (2) Nilai; (3) Ekspektasi.

Berdasarkan hasil penelitian 38 responden $(49,4 \%)$ menyatakan cukup yakin terhadap program-program yang disampaikan oleh kandidat gubernur melalui pemberitaan di media online. Sementara itu 3 responden $(3,9 \%)$ menyatakan sangat yakin terhadap program-program yang disampaikan oleh kandidat gubernur melalui pemberitaan di media online. 29 responden $(37,7 \%)$ menyatakan kurang yakin dan 7 responden $(9,1 \%)$ menyatakan tidak yakin.

Keyakinan tersebut seperti yang dikatakan oleh Nimmo berkaitan dengan kepercayaan terhadap sesuatu hal. Responden masih percaya bahwa kandidat gubernur yang akan mereka pilih nanti akan menjalankan 
program-program yang mereka sampaikan pada saat kampanye di masa kepemimpinannya. Hal ini sebagai konsekuensi dari agenda setting yang ketiga, yang menurut Cutlip, Center dan Broom, adalah semakin masyarakat peduli terhadap sesuatu, semakin mereka ingin mempelajarinya, semakin kuat opini mereka, dan semakin mereka ingin melakukan tindakan tertentu atas isu tersebut. Dalam hal ini adalah semakin kuat keyakinan responden terhadap salah satu kandidat, maka responden akan semakin mencari berbagai informasi mengenai kandidat tersebut dari berbagai media.

Sementara itu kekurangyakinan tersebut selain disebabkan oleh faktor suka dan tidak suka, juga dipengaruhi oleh pengalaman responden terhadap beberapa kepala daerah, yang setelah terpilih melupakan program-program yang mereka sampaikan pada saat kampanye. Bagi responden yang kurang percaya, bahwa program-program yang disampaikan hanya sebatas "lip service" saja dan hanya digunakan untuk menarik simpati pemilih.

Dari 41 responden yang yakin terhadap program-program kandidat gubernur Jabar tahun 2013, menyatakan selalu menyampaikan keyakinan mereka terhadap kandidat tersebut kepada orang lain, hal tersebut disampaikan oleh 15 responden
(19,5\%), sementara itu 26 responden $(33,8 \%)$ menyatakan hanya menyampaikan keyakinan ke beberapa orang yang dikenal dengan dekat saja. Pada umumnya mereka menyampaikan keyakinan tersebut selain secara face to face juga menggunakan media sosial seperti facebook dan twitter, namun kebanyakan dilakukan secara face to face.

Ternyata penyampaian keyakinan secara face to face cukup efektif, meskipun belum seluruh teman-teman responden mengikuti keyakinannya dalam menentukan pilihan terhadap kandidat gubernur Jabar tahun 2013. Dari hasil penelitian diketahui bahwa 8 responden $(10,4 \%)$ menyatakan bahwa seluruh teman-teman mengikuti keyakinan responden untuk memilih kandidat gubernur Jabar tahun 2013 sesuai dengan keyakinan responden. 23 responden $(29,9 \%)$ menyatakan hanya sebagian teman responden yang mengikuti keyakinan reponden terhadap salah satu kandidat gubernur Jabar tahun 2013. 10 responden (13\%) menyatakan hanya beberapa orang teman dekat responden saja yang mengikuti keyakinan responden untuk memilih salah satu kandidat gubernur dalam Pilgub Jabar tahun 2013. Sementara itu 36 responden $(46,7 \%)$ menyatakan tidak ada yang mengikuti keyakinan responden, karena memang responden tersebut tidak pernah menyampaikan keyakinannya kepada orang lain.

Tabel 3

Responden Selalu Menyampaikan Keyakinan tentang Kandidat Pilgub Jabar Tahun 2013 kepada Orang Lain

\begin{tabular}{clcc}
\hline No & \multicolumn{1}{c}{ Uraian } & F & \% \\
\hline 1. & $\begin{array}{l}\text { Ya, selalu menyampaikan keyakinan terhadap kandidat dalam Pilgub Jabar } 2013 \\
\text { kepada orang lain. }\end{array}$ & 15 & 19,5 \\
2. $\quad \begin{array}{l}\text { Hanya menyampaikan keyakinan ke beberapa orang terdekatnya saja. } \\
\text { 3. } \quad \text { Tidak pernah menyampaikan keyakinannya kepada orang lain }\end{array}$ & 26 & 33,8 \\
\hline Jumlah : & 36 & 46,7 \\
\hline
\end{tabular}

Sumber : Hasil Penelitian 


\section{Nilai / Preferensi Mahasiswa}

Perkembangan pemberitaan Pilgub Jabar tahun 2013 di media lainnya ternyata juga diikuti oleh responden selain dari media online. Hal tersebut juga merupakan bagian dari konsekuensi agenda setting media. Setelah sebuah peristiwa menjadi agenda publik, audiens akan mencari informasi atau pemberitaan di media lainnya, karena mereka ingin selalu mengikuti perkembangan pemberitaannya lebih lanjut.

Pemberitaan mengenai Pilgub Jabar tahun 2013 yang secara terus menerus ditampilkan di media online ternyata dibaca oleh responden, dan selalu diikuti perkembangannya, meskipun belum semua responden mengikutinya secara intens. Hasil penelitian menunjukkan, dari 77 responden ternyata hanya 4 responden $(5,2 \%)$ yang selalu mengikuti perkembangan pemberitaan di media online, karena mereka ingin mengetahui terus perkembangan pemberitaan mengenai kandidat gubernur Jabar. Sementara itu 30 responden (39\%) tidak selalu mengikuti perkembangan pemberitaan di media online, 30 responden (39\%) hanya kadang-kadang saja mengikutinya, dan 13 responden $(16,8 \%)$ tidak pernah mengikuti perkembangan pemberitaan di media online.

Pemberitaan mengenai Pilgub Jabar tahun 2013, tidak hanya ramai dibicarakan di media online, tetapi di media-media lainnya seperti surat kabar, televisi, radio, juga ramai membicarakannya. Hasil penelitian menunjukkan, ternyata responden juga mencari informasi di media selain media online. Rincian datanya terlihat pada tabel 4.

Tidak semua responden selalu mencari informasi atau pemberitaan mengenai Pilgub Jabar tahun 2013 di media lain, hal tersebut terkait dengan aktivitas responden yang padat.

Secara keseluruhan pemberitaan mengenai Pilgub Jabar tahun 2013 di media online, banyak disukai oleh responden. Sangat menggembirakan, karena responden yang merupakan pemilih pemula dan generasi muda bisa memberikan suaranya untuk memilih calon pemimpin Jabar untuk lima tahun ke depan.
Hal tersebut juga tidak telepas dari agenda setting media yang terus-menerus menyampaikan pesan-pesannya melalui pemberitaan, sehingga menjadi agenda publik dan menarik minat publik untuk terus mengikutinya. Hasil penelitian menunjukkan bahwa sebagian besar responden yakni 3 responden $(3,9 \%)$ menyatakan sangat menyukai pemberitaan mengenai Pilgub Jabar tahun 2013 dan 53 responden (68,8\%) menyatakan cukup menyukai pemberitaan mengenai Pilgub Jabar tahun 2013. Sementara itu 21 responden $(27,3 \%)$ menyatakan kurang menyukainya. Tabel 5 memuat rincian datanya.

Masih adanya responden yang kurang menyukai pemberitaan Pilgub Jabar tahun 2013 tersebut, sangat wajar karena tidak semua responden memberikan respon yang positif, namun demikian respon positif dari responden yang cukup besar dibandingkan yang negatif, sudah cukup membuktikan agenda setting media telah menjadi agenda publik, dan sangat penting untuk membentuk opini responden.

\section{Ekspektasi Mahasiswa}

Pemahaman dan keyakinan serta kesukaan responden terhadap seluruh pemberitaan mengenai Pilgub Jabar tahun 2013, baik di media online maupun media massa lainnya, telah membentuk opini responden.

Sesuai dengan keyakinan responden, 41 responden, yang terdiri dari 3 responden $(3,9 \%)$ menyatakan sangat mantap dan 38 responden $(49,4 \%)$ menyatakan cukup mantap untuk memilih salah satu kandidat pada saat pemilihan nanti. Dan dari 29 responden yang menyatakan kurang yakin, mereka juga menyatakan ragu-ragu dalam menentukan pilihan salah satu kandidat gubernur dalam Pilgub Jabar tahun 2013. Demikian pula dengan 7 responden $(9,1 \%)$ yang menyatakan tidak yakin ternyata mereka juga menyatakan tidak mantap dalam menentukan salah satu kandidat gubernur Jabar tahun 2013 tersebut. 
Tabel 4

Pencarian Informasi mengenai Pasangan Kandidat Pilgub Jabar Tahun 2013 selain dari Media Online

\begin{tabular}{llcc}
\hline No & Uraian & F & \% \\
\hline 1. & Ya, karena saya peduli dg pilihan saya, maka akan terus mencari informasi di media lain. & 6 & 7,8 \\
& Hanya menyampaikan keyakinan ke beberapa Tidak selalu mencari di media lain, dari media & 38 & 49,4 \\
2. & online saja sudah cukup & & \\
& Kadang-kadang saya mencari informasi mengenai kandidat gubernur Jabar di media lain & 33 & 42,9 \\
3. & $\mathbf{7 7}$ & $\mathbf{1 0 0}$ \\
\hline Jumlah : & &
\end{tabular}

Sumber : Hasil Penelitian

Tabel 5

Kesukaan Responden terhadap Pemberitaan mengenai Pilgub Jabar Tahun 2013 di Media Online

\begin{tabular}{llcc}
\hline No & Uraian & F & \% \\
\hline 1. & Sangat menyukai & 3 & 3,9 \\
2. & Cukup menyukai & 53 & 68,8 \\
3. & Kurang menyukai & 21 & 27,3 \\
4. & Tidak menyukai & 0 & 0 \\
\hline Jumlah : & $\mathbf{7 7}$ & $\mathbf{1 0 0}$ \\
\hline
\end{tabular}

Sumber : Hasil Penelitian

Kemudian bagaimana kecenderungan responden memilih kandidat gubernur sesuai dengan keyakinan mereka? Hasil penelitian menunjukkan 11 responden $(14,3 \%)$ menyatakan memilih kandidat sangat sesuai dengan keyakinan, 30 responden $(38,9 \%)$ menyatakan memilih kandidat cukup sesuai dengan keyakinan. Sementara itu 29 responden $(37,7 \%)$ menyatakan masih raguragu dengan keyakinan mereka, dan 7 responden $(9,1 \%)$ menyatakan pilihan mereka tidak sesuai dengan kayakinan mereka.

\section{Pembahasan}

Untuk mengetahui peran media Online dalam membentuk opini mahasiswa, maka dilakukan penghitungan dengan cara melakukan tabulasi silang antara indikator pemberitaan mengenai Pilgub Jabar tahun 2013 di Media online, yang terdiri dari penonjolan berita, penyajian berita, dan isi berita dengan opini mahasiswa.

Penghitungan melalui tabulasi silang antara penonjolan berita Pilgub Jabar tahun 2013 dengan keyakinan responden, diperoleh data seperti terlihat pada tabel 6 .

Data yang tertera pada tabel 6 memperlihatkan bahwa penonjolan/dominasi pemberitaan Pilgub Jabar tahun 2013 di media online telah meyakinkan responden dan menjadi salah satu faktor yang membentuk opini responden. Teori Agenda Setting ternyata berlaku untuk kasus ini, terlihat bahwa media online telah mengangkat 
isu-isu publik yakni isu-isu mengenai Pilgub Jabar, ke permukaan untuk diketahui publik. Isu yang diberitakan atau ditonjolkan terus menerus akan memengaruhi sikap dan perilaku publik. Isu mengenai Pilgub Jabar tahun 2013, terus diberitakan atau ditonjolkan di media online dan isu tersebut mampu meyakinkan responden dalam membentuk opini mereka. Karena media online terus menerus mengangkat isu tersebut, maka kemudian publik juga mencermati isu-isu tersebut dan mengganggap hal tersebut menjadi penting untuk diketahui lebih lanjut dan akhirnya responden juga berusaha mencari informasi mengenai isu Pilgub Jabar tahun 2013 di berbagai media massa. Meskipun belum semua responden melakukannya.

Penonjolan berita yang kemudian diikuti dengan penyajian berita yang menarik, memberikan keyakinan pada responden dan ini merupakan salah satu faktor yang ikut membentuk opini responden. Rincian datanya tersaji pada tabel 7 .

Penyusunan profil, visi dan misi, program kerja oleh kandidat gubernur dalam Pilgub Jabar tahun 2013 dilakukan untuk memperkenalkan diri mereka ke publik. Penyusunan profil, visi dan misi, program kerja tersebut menjadi acuan bagi kandidat jika mereka terpilih nanti. Berbagai cara dilakukan oleh kandidat agar profil, visi dan misi, serta program kerja mereka menarik untuk dibaca dan diketahui khalayak, yakni dengan memublikasikannya ke berbagai media. Para kandidat telah memiliki situs pribadi dan juga telah membuka akun di media sosial seperti twitter dan facebook, tujuannya adalah agar khalayak mengetahui diri mereka. Profil, visi dan misi, serta program kerja kandidat tidak saja di muat dalam situs pribadi kandidat tetapi juga muncul di berbagai pemberitaan di media online dan ini juga merupakan agenda setting dari media.

Tabel 8 memperlihatkan hasil penelitian mengenai isi profil kandidat, visi dan misi, serta program-program kandidat yang mampu menumbuhkan kesukaan responden terhadap salah satu kandidat. Isi pemberitaan yang memuat mengenai profil, visi dan misi, serta program kerja kandidat, telah menumbuhkan kesukaan pada diri responden untuk terus mengikuti pemberitaan tersebut. Kesukaan merupakan wujud dari nilai yang merupakan preferensi responden. Kesukaan akan menumbuhkan opini dalam diri responden.

Penonjolan berita mengenai Pilgub Jabar tahun 2013 di media online menumbuhkan respon pada diri responden untuk menentukan keyakinan dan kemantapan. Hal tersebut juga merupakan salah satu dari konsekuensi dari agenda setting media. Rincian datanya tersaji pada tabel 9.

Tabel 6

Tabulasi Silang Penonjolan Berita Pilgub Jabar Tahun 2013 di Media Online dengan Keyakinan Responden

\begin{tabular}{|c|c|c|c|c|c|c|c|c|c|c|c|}
\hline \multirow{2}{*}{ No } & \multirow{2}{*}{$\begin{array}{c}\begin{array}{c}\text { Penonjolan } \\
\text { Berita }\end{array} \\
\text { Keyakinan }\end{array}$} & \multicolumn{2}{|c|}{$\begin{array}{c}\text { Sangat } \\
\text { mendominasi }\end{array}$} & \multicolumn{2}{|c|}{$\begin{array}{c}\text { Cukup } \\
\text { mendominasi }\end{array}$} & \multicolumn{2}{|c|}{$\begin{array}{c}\text { Kurang } \\
\text { mendominasi }\end{array}$} & \multicolumn{2}{|c|}{$\begin{array}{c}\text { Tidak } \\
\text { mendominasi } \\
\end{array}$} & \multicolumn{2}{|c|}{ Jumlah } \\
\hline & & $\mathbf{F}$ & $\%$ & $\mathbf{F}$ & $\%$ & $\mathbf{F}$ & $\%$ & $\mathbf{F}$ & $\%$ & $\mathbf{F}$ & $\%$ \\
\hline 1. & Sangat yakin & 3 & 3,9 & - & - & - & - & - & - & 3 & 3,9 \\
\hline 2. & Cukup yakin & 23 & 29,9 & 15 & 19,5 & - & - & - & - & 38 & 49,3 \\
\hline 3. & Kurang yakin & 3 & 3,9 & 19 & 24,7 & 7 & 9,1 & - & - & 29 & 37,7 \\
\hline 4. & Tidak yakin & 5 & 19 & 1 & 1,3 & - & - & 1 & 1,3 & 7 & 9,1 \\
\hline & Jumlah & 34 & 44,2 & 35 & 45,4 & 7 & 9,1 & 1 & 1,3 & 77 & 100 \\
\hline
\end{tabular}

Sumber : Hasil Penelitian 
Tabel 7

Tabulasi Silang Antara Penyajian Berita Pilgub Jabar Tahun 2013 di Media Online dengan Keyakinan Responden

\begin{tabular}{|c|c|c|c|c|c|c|c|c|c|c|c|}
\hline \multirow{2}{*}{ No } & \multirow{2}{*}{$\frac{\text { Penyajian Berita }}{\text { Keyakinan }}$} & \multicolumn{2}{|c|}{ Sangat menarik } & \multicolumn{2}{|c|}{ Cukup menarik } & \multicolumn{2}{|c|}{$\begin{array}{l}\text { Kurang } \\
\text { menarik }\end{array}$} & \multicolumn{2}{|c|}{$\begin{array}{c}\text { Tidak } \\
\text { menarik }\end{array}$} & \multicolumn{2}{|c|}{ Jumlah } \\
\hline & & $\mathbf{F}$ & $\%$ & $\mathbf{F}$ & $\%$ & $\mathbf{F}$ & $\%$ & $\mathbf{F}$ & $\%$ & $\mathbf{F}$ & $\%$ \\
\hline 1. & Sangat yakin & 2 & 2,6 & 1 & 1,3 & - & - & - & - & 3 & 3,9 \\
\hline 2. & Cukup yakin & 1 & 1,3 & 37 & 48,0 & - & - & - & - & 38 & 49,3 \\
\hline 3. & Kurang yakin & - & - & 9 & 11,7 & 20 & 26 & - & - & 29 & 37,7 \\
\hline 4. & Tidak yakin & - & - & 2 & 2,6 & 3 & 3,9 & 2 & 2,6 & 7 & 9,1 \\
\hline & Jumlah: & 3 & 3,9 & 49 & 63,6 & 23 & 29,9 & 2 & 2,6 & 77 & 100 \\
\hline
\end{tabular}

Sumber : Hasil Penelitian

Tabel 8

Tabulasi Silang Isi Profil, Visi \& Misi, Program Kandidat dalam Pilgub Jabar Tahun 2013 di Media Online dengan Kesukaan Responden terhadap Kandidat Pasangan Gubernur

\begin{tabular}{|c|c|c|c|c|c|c|c|c|c|c|c|}
\hline \multirow{2}{*}{ No } & \multirow{2}{*}{$\begin{array}{c}\text { Penonjolan Berita } \\
\begin{array}{c}\text { Kecenderungan } \\
\text { Memilih }\end{array} \\
\end{array}$} & \multicolumn{2}{|c|}{$\begin{array}{c}\text { Sangat } \\
\text { mendominasi }\end{array}$} & \multicolumn{2}{|c|}{$\begin{array}{c}\text { Cukup } \\
\text { mendominasi }\end{array}$} & \multicolumn{2}{|c|}{$\begin{array}{c}\text { Kurang } \\
\text { mendominasi }\end{array}$} & \multicolumn{2}{|c|}{$\begin{array}{c}\text { Tidak } \\
\text { mendominasi }\end{array}$} & \multicolumn{2}{|c|}{ Jumlah } \\
\hline & & $\mathbf{F}$ & $\%$ & $\mathbf{F}$ & $\%$ & $\mathbf{F}$ & $\%$ & $\mathbf{F}$ & $\%$ & $\mathbf{F}$ & $\%$ \\
\hline 1. & Sangat suka & 2 & 2,6 & 1 & 1,3 & - & - & - & - & 3 & 3,9 \\
\hline 2. & Cukup suka & 5 & 6,5 & 33 & 42,8 & - & - & - & - & 53 & 68,8 \\
\hline 3. & Kurang suka & - & - & 3 & 3,9 & 26 & 33,7 & - & - & 21 & 27,3 \\
\hline 4. & Tidak suka & - & - & - & - & 7 & 9,1 & - & - & 0 & 0 \\
\hline & Jumlah: & 7 & 9,1 & 37 & 48 & 33 & 42,8 & 0 & 0 & 77 & 100 \\
\hline
\end{tabular}

Sumber : Hasil Penelitian

Tabel 9

Tabulasi Silang Penonjolan Berita Pilgub Jabar Tahun 2013 dengan Kecenderungan Responden Memilih Kandidat Gubernur

\begin{tabular}{|c|c|c|c|c|c|c|c|c|c|c|c|}
\hline \multirow[b]{2}{*}{ No } & \multirow{2}{*}{$\begin{array}{c}\text { Penonjolan Berita } \\
\begin{array}{c}\text { Kecenderungan } \\
\text { Memilih }\end{array}\end{array}$} & \multicolumn{2}{|c|}{$\begin{array}{c}\text { Sangat } \\
\text { mendominasi }\end{array}$} & \multicolumn{2}{|c|}{$\begin{array}{c}\text { Cukup } \\
\text { mendominasi }\end{array}$} & \multicolumn{2}{|c|}{$\begin{array}{c}\text { Kurang } \\
\text { mendominasi }\end{array}$} & \multicolumn{2}{|c|}{$\begin{array}{c}\text { Tidak } \\
\text { mendominasi } \\
\end{array}$} & \multicolumn{2}{|c|}{ Jumlah } \\
\hline & & $\mathbf{F}$ & $\%$ & $\mathbf{F}$ & $\%$ & $\mathbf{F}$ & $\%$ & $\mathbf{F}$ & $\%$ & $\mathbf{F}$ & $\%$ \\
\hline 1. & $\begin{array}{l}\text { Sangat sesuai dengan } \\
\text { keyakinan }\end{array}$ & 8 & 10,4 & 3 & 3,9 & - & - & - & - & 11 & 14,3 \\
\hline 2. & $\begin{array}{l}\text { Cukup sesuai dengan } \\
\text { keyakinan }\end{array}$ & 26 & 33,8 & 3 & 3,9 & 1 & 1,3 & - & - & 30 & 38,9 \\
\hline 3. & $\begin{array}{l}\text { Kurang sesuai dengan } \\
\text { keyakinan }\end{array}$ & - & - & 25 & 32,4 & 4 & 5,2 & - & - & 29 & 37,7 \\
\hline 4. & $\begin{array}{l}\text { Tidak sesuai dengan } \\
\text { keyakinan }\end{array}$ & - & - & 4 & 5,2 & 2 & 2,6 & 1 & 1,3 & 7 & 9,1 \\
\hline & Jumlah: & 34 & 44,2 & 35 & 45,4 & 7 & 9,1 & 1 & 1,3 & 77 & 100 \\
\hline
\end{tabular}

Sumber : Hasil Penelitian 
Penonjolan berita Pilgub Jabar tahun 2013 di media online berdasarkan hasil penelitian telah memantapkan responden terlihat dari kecenderungan untuk memilih salah satu kandidat dalam Pilgub Jabar tahun 2013. Kecenderungan memilih merupakan salah satu aspek dari opini publik yakni ekspektasi responden. Responden akan mengonstruksikan tindakannya berdasarkan pemahaman yang mereka peroleh dari berbagai pemberitaan mengenai Pilgub Jabar tahun 2013 dan juga dari berbagai pengetahuan yang mereka dapat di luar media massa.

\section{PENUTUP}

\section{Simpulan}

Penonjolan pemberitaan Pilgub Jabar tahun 2013 di media online telah membentuk opini mahasiswa, penonjolan pemberitaan ditunjukkan dengan dominasi pemberitaan proses Pilgub Jabar hingga pemberitaan kelima pasang kandidat gubernur Jabar di media online.

Penyajian berita Pilgub Jabar tahun 2013 di media online telah membentuk opini mahasiswa, penyajian berita yang menarik di media online ditunjukkan dengan kecepatan dan kemudahan responden untuk mendapakan informasi mengenai Pilgub Jabar tahun 2013. Responden tidak harus mengeluarkan biaya untuk terus mengikuti pemberitaannya. Penyediaan ruang untuk berinteraksi dan memberikan komentar di setiap pemberitaan Pilgub Jabar di media online juga menjadi daya tarik bagi responden untuk terus mengikuti pemberitaannya.

Isi pemberitaan Pilgub Jabar tahun 2013 di media online telah membentuk opini mahasiswa, isi berita ditunjukkan dengan profil kandidat, visi dan misi kandidat, program-program kandidat, aktivitas kampanye kandidat di media online.

\section{Saran}

Banyak sisi positif yang bisa didapat dari internet dalam hal ini media online, salah satunya adalah kemudahan dalam memperoleh berbagai jenis informasi maupun berita, sesperti berita mengenai Pilgub Jabar tahun 2013. Oleh karena itu pemerintah perlu terus mengembangkan sarana dan prasarana TIK tersebut, terutama di daerah-daerah perdesaan, agar masyarakat di perdesaan ke depan juga bisa ikut memanfaatkan kemajuan TIK sehingga bisa mendapatkan berbagai informasi seperti pemberitaan mengenai Pilkada.

Penggalangan suara dalam Pilkada melalui media online sudah semakin sering dilakukan oleh para kandidat, oleh karenanya diperlukan kreativitas dari para tim sukses, agar bisa mengemas berita/informasi semenarik mungkin, sehingga akan lebih banyak lagi masyarakat yang tertarik untuk mengikuti pemberitaan mengenai Pilkada melalui media online.

\section{DAFTAR PUSTAKA}

\section{Buku :}

Albig, William. (1939). Public Opinion. New York: Mc.Graw-Hill Book Company, Inc.

Alisjahbana, Iskandar. (2001). Evolusi Pembaruan Budidaya Masyarakat Terbuka Global. Dalam Sonny Yuliar,dkk. Editor. Memotret Telematika Indonesia Menyongsong Masyarakat Informasi Nusantara. Bandung: Pustaka Hidayah.

Cutlip, Scott M, Allen H.Center, Glen M.Broom. (2000). Effective Public Relations. USA: Prentice Hall.

LaQuay, Tracy. (1997). Sahabat Internet: Pedoman Bagi Pemula Untuk Memasuki Jaringan Global. Edisi 2. Bandung: Penerbit ITB.

Luik, Jandy E. (2011). Media Sosial dan Presentasi Diri. Dalam Junaedi, Fajar Ed.Komunikasi 2.0 Teoritisasi dan Implikasi.Yogyakarta: Mata Padi Pressindo.

Nimmo, Dan. (2005). Komunikasi Politik, Komunikator, Pesan, dan Media.Bandung: $\quad$ PT Remaja Rosdakarya.

Rahardjo,Turnomo. (2011). Isu-isu Teoritis 
Media Sosial. Dalam Junaedi, Fajar Ed. Komunikasi 2.0 Teoritisasi dan Implikasi.Yogyakarta: Mata Padi Pressindo.

Rakmat, Djalaluddin. (2005). Metode Penelitian Komunikasi. Bandung: PT Remaja Rosdakarya.

Santosa, Hedi Pudjo. (2011). Implikasi Media Sosial Pada Perkembangan Ilmu Komunikasi. Dalam Junaedi, Fajar Ed. Komunikasi 2.0 Teoritisasi dan Implikasi.Yogyakarta:Mata Padi Pressindo.

Severin, Werner J dan James W.Tankard, Jr. (2007). Teori Komunikasi, Sejarah, Metode, dan Terapan di Dalam Media Massa Edisi kelima. Jakarta: Kencana Prenada Media Group.

Singarimbun, Masri dan Sofyan, Effendy. (1989). Metode Penelitian Survey. Jakarta: LP3ES.

Tabroni,Roni. (2012). Komunikasi Politik Pada Era Multimedia. Bandung: Simbiosa Rekatama Media.

\section{Sumber Lainnya: \\ Jurnal:}

Yenni, Yuniati. (2002). Pengaruh Berita di Surat Kabar terhadap Persepsi Mahasiswa tentang Politik. Mediator Jurnal Komunikasi, volume 3. No.1 Tahun 2002, hal 91.

\section{Surat Kabar:}

Rizal, Yose. (2012). Kandidat Butuh Bauran Media. Pikiran Rakyat.13 Desember.
Halaman 3.

(2013). Optimalkan Akun Kandidat. Pikiran Rakyat.10

Desember.Halaman 3. (2012). "Berperang" di Media Sosial. Pikiran Rakyat. 22 November. Halaman 3.

\section{Internet:}

Amiruddin. (2009). Peran Media Dalam Pembentukan Opini Masyarakat di Wilayah Perbatasan mengenai Jatidiri Bangsa Indonesia. Tersedia dalam

$<$ http://www.isjd.pdii.lipi.go.id/..../11 1105980 1411-139 >. Diakses tanggal 8 Januari 2013.

Anonim. (2013). Pemilih Pilgub Jabar 2013 sebanyak 32,5 juta orang. Tersedia dalam

$<$ http://www.reportase.com/2013/01/ pemilih-pilgub-jabar-2013-

sebanyak-32-5-juta-orang $>$. Diakses tanggal 7 Maret 2013.

Ceritarara. ( 2012). Negara dengan Jumlah Pengguna Internet Terbesar (Internet Word Stats), Tersedia dalam $<$ http://ceritarara.wordpress.com>.

Diakses pada tanggal 1September 2012.

Yesicha, Chesy. (2011). Pengertian Opini Publik. Tersedia dalam $<$ http://www.chesyyesicha.staff.unri. ac.id/files/.../OP1.pdf $>$. Diakses tanggal 21 Januari 2013. 